\title{
Morphological Characteristics and Leaf Pigment Contents of Isogenic-diploid and Tetraploid Pearl Millet Inbred Lines
}

\author{
M. Dujardin, C. Krien \\ Agronomy Department, University of Georgia, \\ College of Agriculture Exp. Stations, Coastal Plain Exp. Station, \\ Tifton, GA 31793, U.S.A. \\ and \\ W. W. Hanna \\ USDA-ARS, Agronomy Department, \\ Univeristy of Georgia, College of Agriculture Exp. Stations, \\ Coastal Plain Exp. Station, Tifton, GA 31793, U.S.A.
}

Accepted March 10, 1989

Pearl millet, Pennisetum glaucum (L.) R. Br. is an annual diploid $(2 \mathrm{n}=14)$ species grown primarily for forage in the USA. Autotetraploid pearl millet has been repeatedly induced (Gill et al. 1969, Hanna et al. 1976, Jauhar 1981) but so far, tetraploids have been of little immediate benefit to pearl millet improvement because of poor seed set. However, potential exists to improve tetraploid pearl millet fertility by increasing heterozygosity (Dujardin and Hanna 1988). In addition, induced autoploidy in pearl millet plays an important bridging role in enhancing the crossability with other Pennisetum species and in facilitating gene flow (Hanna and Dujardin 1985).

A primary effect of chromosome doubling is an increase in cell size (Stebbins 1950). Induced autotetraploids derived from diploid pearl milles inbred Tift 239DB were characterized by larger stomatal guard cells, larger pollen grains and longer stigmatic hairs on the pistils (Hanna et al. 1976).

The expression of induced polyploidy in plant organs has been investigated in a number of cereals, such as tetraploid maize (Randolph et al. 1944), rye (Müntzing 1951), sorghum (Schertz 1962), pearl millet (Hanna et al. 1976) and Triticum monococcum (Kuspira et al. 1985).

The effects of ploidy on a number of morphological characteristics in isogenic triploid and hexaploid pearl millet $\times$ napiergrass hybrids showed differential responses among clones (Gonzalez and Hanna 1984). Increased ploidy from $3 \mathrm{x}$ to $6 \mathrm{x}$ in these interspecific hybrids had generally a neutral or negative effect on forage yield and quality (Hanna et al. 1976).

The existing knowledge of physiological changes associated with genome multiplication is still fragmentary (Lewis 1980). Generally, leaves of tetraploid plants contain less chlorophyll than diploids; however, per unit area, tetraploids are richer in chlorophyll and have higher pigment concentration than their diploid progenitors (Lewis 1980). Warner et al. (1987) found that tetraploid pearl millet inbred Tift 239DB had $50 \%$ fewer photosynthetic cells per unit leaf area, but twice as many chloroplasts per cell than the diploid isoline, resulting in similar chlorophyll content and photosynthetic enzyme activities on a leaf area basis.

Over the years, there have been numerous studies comparing tetraploids with diploids for various characteristics. However, most previous studies have used a single genotype in a single experiment. The purpose of this research was to develop new tetraploid inbred lines of pearl millet in order to enlarge the tetraploid gene pool and to evaluate the ploidy effects on several morphological and chemical characteristics in three isogenic diploid ( $2 \mathrm{n}=$ 
14)-tetraploid $(2 \mathrm{n}=28)$ pearl millet inbred lines grown at two planting dates.

\section{Materials and methods}

Diploid $(2 n=2 x=14)$ and tetraploid $(2 n=4 x=28)$ pearl millet inbred lines used in this study were 'Tift 23BE' (green plant), 'Tift 239DB' (green plant) and 'Tift 23R' (a red plant due to a dominant gene).

Tetraploid inbreds 23BE and 23R were induced by immersing soaked seed for 6 hours in a $0.1 \%$ colchicine solution. Tetraploid Tift $237 \mathrm{DB}(2 \mathrm{n}=28)$ has been described previously (Hanna et al. 1976). Somatic chromosome counts were made from root-tips pretreated for 2 hours in a saturated solution of monobromonaphthalene, hydrolyzed for $8 \mathrm{~min}$. in 5 $\mathrm{N} \mathrm{HCl}$ at room temperature and stained in Feulgen's reagent. The three diploid inbred lines and their three tetraploid isolines were planted in the field in 1987.

The experiments were arranged in a randomized complete block design with 5 replications. Plots consisted of 2 rows, each $5 \mathrm{~m}$ long with $0.9 \mathrm{~m}$ between rows. Plants were thinned to one plant every $0.3 \mathrm{~m}$ at three weeks after planting. The test was planted on 26 May, 1987 and 30 June, 1987. The first planting allowed plants to reach anthesis under increasing day lengths while plants in the second planting reached anthesis under decreasing day lengths. Plots received $275 \mathrm{~kg} / \mathrm{ha} 5-10-15$ fertilizer at planting.

Data were recorded for 1) number of days to flowering-stigmas exserted on $50 \%$ of panicles per plot, 2) plant height-average height from ground to tip of inflorescence on plants in each plot, 3) leaf length and leaf width at the third internode from the top of the plant on 5 plants in each plot, 4) panicle length on 10 plants in each plot, 5) seed weight per panicle from 10 panicles per plot, 6) one hundred seed weight from one plant per plot, and 7) $a$ and $b$ chlorophyll, carotene, and anthocyanin (for 23R) concentrations in the leaf.

Leaf pigment concentrations were determined on the most recently mature leaf of 10 plants per replication of the 30 June planting. The midrib of the leaf was removed and the center third of the leaf was used for all determinations. Leaves were cut into $2 \mathrm{~cm}$ square sections, subsampled and leaves mixed, and four $5 \mathrm{~g}$ samples withdrawn for determinations. Chlorophyll a and carotene concentrations were determined according to the procedures of Devlin et al. (1978). Anthocyanins were extracted and total anthocyanin concentration was determined as developed by Fuleki and Francis (1968a, b).

References to significant is at $\mathbf{P}=0.05$.

\section{Results and discussion}

The means for number of days to flowering, plant height, panicle length, leaf length, leaf width, seed weight per panicle, and one hundred seed weight for the 26 May and 30 June plantings are given in Table 1. Tetraploid inbreds 23BE and 239DB on the average flowered 4.1 and 3.4 days later, respectively, than their diploid isolines. Although tetraploid 23R tended to flower later than diploid $23 \mathrm{R}$, the small differences were significant at only the 30 June planting date. Each inbred flowered significantly earlier at the 30 June planting compared to the 26 May planting due to the shorter and decreasing day lengths during the flower initiation period of the 30 June planting. No ploidy $x$ planting date interaction was observed, indicating that the same response for days to flowering due to ploidy was observed in both plantings.

Tetraploid inbreds $23 \mathrm{BE}$ and $239 \mathrm{DB}$ tended to be shorter than their $2 \mathrm{x}$ counterparts at both plantings, but the differences were significant only at the 26 May planting. In contrast, $4 \mathrm{x}$ inbred $23 \mathrm{R}$ averaged $27 \%$ taller than its $2 \mathrm{x}$ counterpart. Height of $2 \mathrm{x}$ and $4 \mathrm{x}$ plants of 
all inbreds were significantly shorter in the 30 June planting compared to the 26 May planting.

Average panicle lengths of $2 \times 23 \mathrm{BE}$ and $239 \mathrm{DB}$ were significantly longer than panicles from $4 x$ plants of the same inbreds. The differences between $2 x$ and $4 x$ plants of these two inbreds were small and probably of little practical significance. However, panicles of $4 \mathrm{x}$ $23 R$ averaged $5.2 \mathrm{~cm}$ longer than panicles of $2 x 23 R$. Panicles on 23BE and 239DB plants in the 30 June plantings were significantly shorter than panicles from the 26 May planting. The shorter panicles, shorter height and fewer days to flowering of these inbreds in the 30 June planting compared to the 26 May planting are probably due to the onset of shorter days influencing the plant life cycle in the 30 June planting.

Differences in leaf length and width between $2 x$ and $4 x$ plants of inbreds 23BE and 239DB were small and varied between plantings. Tetraploid plants of both inbreds had wider leaves in the 26 May planting than diploid plants. However, a significant differences for leaf length was only observed for 23BE at the 26 May planting when $4 \mathrm{x}$ plant leaves were $3.3 \mathrm{~cm}$ longer than $2 x$ plant leaves. Large differences were observed for $23 R$ where on the average $4 x$ plants had significantly longer $(17.2 \mathrm{~cm})$ and wider $(1.05 \mathrm{~cm})$ leaves than $2 x$ plants.

Table 1. Means of the 26 May and 30 June planting dates for days to flowering, height, panicle length, leaf length, leaf width, seed weight per panicle, and one hunderd seed weight in isogenic diploid and tetraploid pearl millet

\begin{tabular}{ccccccccc}
\hline \hline $\begin{array}{c}\text { Inbred } \\
\text { lines }\end{array}$ & $\begin{array}{c}\text { Ploidy } \\
\text { level }\end{array}$ & $\begin{array}{c}\text { Days to } \\
\text { flowering }\end{array}$ & Height & $\begin{array}{c}\text { Panicle } \\
\text { length }\end{array}$ & $\begin{array}{c}\text { Leaf } \\
\text { length }\end{array}$ & $\begin{array}{c}\text { Leaf } \\
\text { width }\end{array}$ & $\begin{array}{c}\text { Seed weight/ } \\
\text { panicle }\end{array}$ & $\begin{array}{c}100 \text { seed } \\
\text { weight }\end{array}$ \\
\hline \multirow{2}{*}{ Tift 23BE } & $2 \mathrm{x}$ & $50.1 \mathrm{~b}$ & $136 \mathrm{a}$ & $20.4 \mathrm{a}$ & $51.1 \mathrm{~b}$ & $2.75 \mathrm{a}$ & $9.30 \mathrm{a}$ & $0.64 \mathrm{a}$ \\
& $4 \mathrm{x}$ & $54.2 \mathrm{a}$ & $122 \mathrm{~b}$ & $18.9 \mathrm{~b}$ & $53.2 \mathrm{a}$ & $2.82 \mathrm{a}$ & $0.20 \mathrm{~b}$ & $0.51 \mathrm{~b}$ \\
Tift 239DB & $2 \mathrm{x}$ & $67.5 \mathrm{~b}$ & $130 \mathrm{a}$ & $23.9 \mathrm{a}$ & $64.2 \mathrm{a}$ & $3.13 \mathrm{~b}$ & $2.40 \mathrm{a}$ & $0.38 \mathrm{~b}$ \\
& $4 \mathrm{x}$ & $70.9 \mathrm{a}$ & $119 \mathrm{~b}$ & $23.3 \mathrm{~b}$ & $64.5 \mathrm{a}$ & $3.41 \mathrm{a}$ & $0.40 \mathrm{~b}$ & $0.45 \mathrm{a}$ \\
Tift 23Red & $2 \mathrm{x}$ & $73.4 \mathrm{a}$ & $174 \mathrm{~b}$ & $19.1 \mathrm{~b}$ & $63.1 \mathrm{~b}$ & $2.73 \mathrm{~b}$ & $1.28 \mathrm{a}$ & $0.39 \mathrm{~b}$ \\
& $4 \mathrm{x}$ & $74.4 \mathrm{a}$ & $221 \mathrm{a}$ & $24.3 \mathrm{a}$ & $80.3 \mathrm{a}$ & $3.78 \mathrm{a}$ & $1.53 \mathrm{a}$ & $0.61 \mathrm{a}$ \\
\hline
\end{tabular}

Means followed by the same letter in columns for an inbred line are not significant at $P=0.05$.

Seed weight per panicle was significantly reduced from the diploid to tetraploid level in inbreds $23 \mathrm{BE}$ and $239 \mathrm{DB}$ due to high ovule abortion. However, tetraploid 23R produced on the average as much seed as its diploid isoline. There was a significant planting date response for seed production per panicle on $23 \mathrm{R}$ due probably to more droughty growing conditions during the second planting. A significant planting date $\mathrm{x}$ ploidy interaction for seed weight per panicle was observed for $23 R$. At the 26 May planting, $4 x$ 23R plants set significantly more seed per panicle than $2 x 23 \mathrm{R}$ plants whereas the reverse was true for the 30 June planting.

Average weight per 100 seeds were significantly higher for $4 x 239 D B$ and $23 R$ than for their $2 \mathrm{x}$ isolines, whereas the opposite response was observed for inbred 23BE. Increased seed size is usually associated with decreased seed set as observed for $239 \mathrm{DB}$ at both planting dates. A significant planting date response for all inbreds is reflected in the reduced seed size in the second planting compared to the first planting. There was also a significant ploidy $x$ planting date response for $23 \mathrm{BE}$ and $23 \mathrm{R}$.

Chlorophyll $\mathrm{a}$ and $\mathrm{b}$ concentrations (Table 2) were similar in both diploid and tetraploid inbreds 239DB and 23R. The tetraploid inbred 23BE, however had significantly higher chlorophyll a concentration than did the diploid.

Carotene concentrations were similar at the diploid and tetraploid level for inbred 239DB. Significantly lower carotene levels were present in tetraploid inbred $23 \mathrm{BE}$ than in its diploid 
counterpart. Carotene concentration in inbred 23R was approximately three times higher at the tetraploid than at the diploid levels. Anthocyanin weight per gram leaf dry weight also increased by $100 \%$ in tetraploid inbred $23 \mathrm{R}$ when compared to the diploid. Increase in anthocyanin concentration was reflected in $4 x$ red plants having a darker red color than 2x 23R plants.

\section{Discussion}

Tetraploidy in different inbreds of pearl millet produced different results for a number of the characters measured indicating a genotype influence. Similarly, all morphological characters were not affected the same way by an increase in ploidy from the $3 x$ to the $6 x$ level in isogenic triploid-hexaploid pearl millet $\times$ napiergrass hybrids (Gonzalez and Hanna 1984). Although trends for the characters measured were similar for the two planting dates, the differences were more evident in the 26 May planting with favorable growing conditions (good soil moisture, increasing day length, and few leaf diseases) compared to the 30 June planting (drought, decreasing day length, and leaf diseases) indicating a need to have good growing

Table 2. Chlorophyll $a$ and $b$ and carotene optical densities and anthocyanin concentrations in isogenic diploid and tetraploid pearl millet

\begin{tabular}{cccccc}
\hline \hline \multirow{2}{*}{ Inbred line } & Ploidy level & \multicolumn{2}{c}{ Chlorophyll } & Carotene & $\begin{array}{c}\text { Anthocyanin } \\
\text { mg/g leaf dry weight }\end{array}$ \\
\cline { 3 - 4 } & & $\mathrm{a}$ & $\mathrm{b}$ & & \\
\cline { 3 - 5 } $23 \mathrm{BE}$ & $2 \mathrm{x}$ & $297 \mathrm{~b}$ & $272 \mathrm{a}$ & $109 \mathrm{a}$ & \\
& $4 \mathrm{x}$ & $368 \mathrm{a}$ & $312 \mathrm{a}$ & $72 \mathrm{~b}$ & \\
$239 \mathrm{DB}$ & $2 \mathrm{x}$ & $361 \mathrm{a}$ & $299 \mathrm{a}$ & $108 \mathrm{a}$ & \\
& $4 \mathrm{x}$ & $350 \mathrm{a}$ & $284 \mathrm{a}$ & $122 \mathrm{a}$ & $50 \mathrm{~b}$ \\
$23 \mathrm{R}$ & $2 \mathrm{x}$ & $310 \mathrm{a}$ & $273 \mathrm{a}$ & $35 \mathrm{~b}$ & $105 \mathrm{a}$ \\
\hline
\end{tabular}

Means followed by the same letter in columns for an inbred line are not significant at $P=0.05$. Optical density (OD) at $645 \mathrm{~nm}$ and $663 \mathrm{~nm}$ for chlorophyll a and b, respectively.

Optical density at $440 \mathrm{~nm}$ and $666 \mathrm{~nm}$.

conditions to maximize the chances for distinguishing ploidy effects. Significant planting date responses were usually reflected in smaller values for the 30 June planting due to environmental conditions. The few significant ploidy $x$ planting date interactions observed in this study indicated that ploidy may cause certain characters to respond differently in different environments.

\section{Summary}

Inbreds with different ploidy level allow for the study of ploidy-genotype effects on various agronomic, morphological and physiological characteristics. Isogenic diploid $(2 \mathrm{n}=$ 14)-tetraploid $(2 \mathrm{n}=28)$ pearl millet (Pennisetum glaucum (L.) R. Br.) inbred lines Tift 23BE, Tift 239DB and Tift 23R (red plant) grown at two planting dates were evaluated in replicated tests for polyploidy effects on several morphological characteristics and leaf pigment contents. Tetraploid inbred lines 23BE and 239DB flowered later, were shorter and produced smaller panicles with less seed, but showed small or non-significant differences in length and width, and one hundred seed weight. However, tetraploid inbred 23R averaged significantly higher than the diploid in all characteristics except number of days to flowering and seed weight per 
panicle. Chlorophyll $\mathrm{a}$ and $\mathrm{b}$ were in similar concentrations among diploid and tetraploid inbreds, except for tetraploid inbred $23 \mathrm{BE}$ which had higher chlorophyll a concentration. Carotene and anthocyanin concentrations increased by $300 \%$ and $100 \%$, respectively, from the diploid to the tetraploid level in inbred 23R. The data indicated that changes in morphological characteristics were due to ploidy, plant genotype, and/or environmental conditions. A 26 May planting date with increasing day lengths was more effective for distinguishing ploidy effects than a 30 June planting date with decreasing day lengths.

\section{Acknowledgements}

Contribution of USDA-ARS in cooperation with the University of Georgia Agricultural Experiment Stations. Study support in part by the U. S. Department of Energy Contract No. DE-AS09-76-EV00637 and Competitive Grant No. 81-CRCR-1-1002.

\section{Literature cited}

Devlin, R. M., Saras, C. N., Kisiel, M. J. and Kostusiak, A. S. 1978. Influence of fluridone on chlorophyll content of wheat (Triticum aestivum) and corn (Zea mays). Weed Sci. 26: 432-433.

Dujardin, M. and Hanna, W. W. 1988. Fertility improvement in tetraploid pearl millet. Euphytica (in press).

Fuleki, T. and Francis, F. J. 1968a. Quantitative methods for anthocyanins 1. Extraction and determination of total anthocyanin in cranberries. J. of Food Sci. 33: 72-77.

- and $-1968 \mathrm{~b}$. Quantitative methods for anthocyanins 2. Determination of total anthocyanin and degradation index for cranberry juice. J, of Food Sci. 33: 78-83.

Gill, B. S., Minocha, J. L., Gupta, D. and Kumar, D. 1969. Chromosome behaviour and seed setting in autotetraploid pearl millet. Indian J. Genet. Plant Breeding 29: 462-467.

Gonzalez, B. and Hanna, W. W. 1984. Morphological and fertility responses in isogenic triploid and hexaploid pearl millet $\times$ napiergrass hybrids. Jour. Heredity $75: 317-318$.

Hanna, W. W. and Dujardin, M. 1985. Interspecific transfer of apomixis in Pennisetum. Proc. of the XV Intern. Grassl. Congr., Kyoto, Japan, pp. 249-250.

-, Gaines, T. P., Gonzalez, B. and Monson, W. G. 1984. Effect of ploidy on yield and quality of pearl millet $\times$ napiergrass hybrids. Agron. Jour. 76: 969-971.

-, Powell, J. B. and Burton, G. W. 1976. Relationship to polyembryony, frequency, morphology, reproductive behavior, and cytology of autotetraploids in Pennisetum americanum. Can. J. Genet. Cytol. 18: 529536.

Jauhar, P. P. 1981. Cytogenetics and Breeding of Pearl Millet and Related Species. Alan R. Liss, Inc., New York.

Kuspira, J., Bhambhani, R. N. and Shimada, T. 1985. Genetic and cytogenetic analyses of the A genome of Triticum monococcum I. Cytology, breeding behavior, fertility and morphology of induced autotetraploids. Can. J. Genet. Cytol. 27: 51-63.

Lewis, W. H. 1980. Polyploidy, Biological Relevance. Plenum Press, New York and London.

Müntzing, A. 1951. Cytogenetics properties and practical value of tetraploid rye. Hereditas 37: 18-84.

Randolph, L. F., Abbe, E. C. and Einset, J. 1944 . Comparison of shoot apex and leaf development and structure in diploid and tetraploid maize. Jour. Agr. Res. 69: 47-76.

Schertz, K. F. 1962. Cytology, fertility and gross morphology of induced polyploidy of Sorghum. Can. J. Genet. Cytol. 4: 179-186.

Stebbins, G. L. 1950. Variation and Evolution in Plants. Columbia University Press, New York.

Warner, D. A., Ku, M. S. B. and Edward, G. E. 1987. Photosynthesis and leaf anatomy in diploid and tetraploid Pennisetum americanum. Plant Physiology 83 (4, Supplem.): 33. 